\title{
Literatura
}





\section{Alegoria e símbolo em torno do Fausto de Goethe} MARCUS V. MAZZARI I

Para Alfredo Bosi, que iluminou os procedimentos alegórico e simbólico nas "flechas opostas" de Anchieta e na "Máquina do Mundo" drummondiana.

Se o senhor puder tornar-lbe [ao pintor Martin Wagner] compreensivel a diferença entre tratamento alegórico e simbólico, o senhor será seu benfeitor, pois muita coisa se move em torno desse eixo.

(Goethe ao filósofo Schelling em carta de 29 de novembro de 1803)

\section{Atualidade de um clássico}

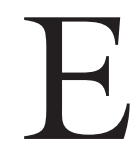

M SEUS anos de velhice, Goethe não apenas concebeu a ideia de "literatura mundial" (Weltliteratur), como também lhe legou, com a Segunda Parte do Fausto, uma das mais altas realizações do espírito humano. Introduzindo o herói pactário na esfera dos negócios estatais do Palatinado Imperial, palco de seis cenas no primeiro ato, Goethe nos descortina o "grande mundo" também prometido por Mefistófeles no limiar das aventuras pelo piccolo mondo que se constitui, na Primeira Parte, ao redor da figura de Margarida. E no quinto ato, quando se abre a derradeira etapa na trajetória terrena de Fausto em meio ao desabrochar de uma nova civilização em espaços conquistados ao mar, questões que haviam sido lançadas no início da tragédia (em especial as apostas de Mefisto com Deus e com Fausto, delineadas no "Prólogo no céu" e na primeira cena "Quarto de trabalho") são levadas a um desfecho, concluindo-se assim o grande clássico da literatura alemã. "Desfecho" ou "conclusão", contudo, não significa uma resolução inequívoca de tais questões, uma vez que no Fausto II, "à semelhança da história do mundo e dos homens" - conforme escrevia Goethe a Carl Friedrich Reinhard em 7 de setembro de 1831 - "o último problema solucionado sempre coloca um novo problema a ser solucionado".

Formulações como essa não são raras em cartas goethianas, o que respaldaria a suposição - se for lícito dar logo de início um passo ousado - de que o velho mestre de Weimar talvez pudesse reconhecer concepções próprias na observação de Adorno sobre o "duplo caráter” da obra artística enquanto "autonomia e fait social", de sua dimensão enigmática que, se por um lado não se deixa traduzir em linguagem conceitual, por outro depende dessa para liberar e fazer veicular o seu teor - ou, conforme se lê numa passagem da Teoria estética (segmento "Caráter enigmático e compreensão"): “solver o enigma equivale a 
indicar a razão de sua insolubilidade". ${ }^{1}$ Goethe procurou aproximar-se por vezes desse dilema da "insolubilidade" mobilizando o adjetivo "incomensurável", e na extraordinária conversa com Eckermann datada de 6 de maio de 1827, após negar com veemência ter trabalhado no Fausto segundo qualquer “ideia”, diz: "quanto mais incomensurável for uma produção poética, quanto mais inapreensível para o entendimento, tanto melhor". 2 Seria legítimo sustentar assim que, com a publicação póstuma da Segunda Parte da tragédia Fausto, a literatura alemã (e mundial) ganha o seu clássico mais ambivalente e "incomensurável" (ou também “insolúvel”), pois vem a lume uma obra que, trazendo consigo "suficientes problemas", oferece ao leitor, em vez de elucidação, apenas "gestos, acenos e leves alusões", que o convidam a encontrar na obra muito mais coisas do que o próprio poeta pôde colocar de maneira consciente. ${ }^{3}$ Neste ponto não estaríamos distantes da observação que faz Erich Auerbach, no XIV capítulo de Mimesis, sobre a tendência, sobretudo a partir do romantismo, a extrair do grande clássico da literatura espanhola coisas que Cervantes sequer podia pressentir: "Tais reinterpretações e hiperinterpretações de um texto antigo são frequentemente produtivas: um livro como o Dom Quixote desprende-se da intenção de seu autor e leva sua própria vida; mostra a cada período que nele encontra prazer um rosto novo".

Se, portanto, o termo “clássico”, na acepção aqui delineada, caracteriza uma obra que permanece significativa nos mais variados contextos históricos e culturais, submetida a uma recepção contínua e sempre apresentando novas fisionomias às sucessivas gerações de leitores, então talvez se possa efetivamente dizer que a tragédia na qual Goethe trabalhou ao longo de seis décadas merece esse qualificativo mais do que qualquer outro "clássico" da literatura mundial. 4

Não surpreende assim que, numa abordagem da tragédia sob o ponto de vista da economia moderna e de suas crises, o intérprete (renomado economista suíço) se lance logo de início à seguinte afirmação:

O Fausto de Goethe é de uma atualidade quase que inimaginável. De todos os dramas escritos até hoje ele é o mais moderno. Ele coloca em primeiro plano um tema que, mais do que qualquer outro, domina os tempos atuais: o fascínio que emana da economia. [...] Ele explica a economia como um processo alquímico: como a busca pelo ouro artificial, uma busca que rapidamente se converte em obsessão para aquele que se consagra a isso. Quem não entende a alquimia da economia, eis a mensagem do Fausto goethiano, não consegue captar a colossal dimensão da economia moderna. ${ }^{5}$

Essa "colossal dimensão" culmina, segundo a perspectiva de Hans Christoph Binswanger, no quinto ato da Segunda Parte, uma vez que o projeto colonizador que aí se desdobra estaria sendo financiado pelo plano econômico (esteado na criação do papel-moeda) do primeiro ato e, por conseguinte, por uma espécie de poderosa instituição bancária que, nas palavras do intérprete, poderia chamar-se "Fausto \& Mefistófeles S. A.”. 
Não deixa de ser uma interpretação discutível, pois os vínculos entre a criação do papel-moeda nas primeiras cenas ambientadas no Palatinado Imperial e a expansão do império fáustico no último ato de modo algum estão manifestos no texto goethiano. No entanto, ao proceder a essa leitura do Fausto à luz da economia moderna, Binswanger não faz senão corresponder àquela expectativa goethiana de que futuros leitores pudessem encontrar no texto "mais coisas" do que ele mesmo foi capaz de pôr. $\mathrm{O}$ intérprete constrói assim sua própria coerência, e ao leitor de seu estudo se abre, por meio da via econômica, uma nova visada para as riquezas inesgotáveis do texto, entre as quais está justamente a configuração, em cenas do primeiro e do quinto atos da Segunda Parte, de tendências históricas e sociais ainda incipientes no tempo de Goethe, mas que começam a intensificar-se sobremaneira nos decênios posteriores à sua morte em março de 1832, e parecem atingir, com os desdobramentos contemporâneos da globalização, níveis que se superam continuamente.

Nas três primeiras cenas do quinto ato, o poeta nos apresenta, numa "região aberta" (título da primeira), o pequeno espaço habitado pelo casal de anciãos Filemon e Baucis; mostra-nos ainda o seu progressivo estrangulamento pela ampliação do domínio fáustico, e, por fim, as chamas que consomem os corpos dos anciãos assim como de um visitante (e hóspede) que recebe apenas a designação de "Peregrino". Mas também três outros atributos dessa esfera outrora idílica sucumbem ao fogo: uma cabana, uma capela e um par de tílias. O que representa essa devastação na última etapa do drama goethiano? Ou, mais particularmente, que significado se poderia atribuir à destruição das árvores mencionadas logo no primeiro verso do quinto ato, quando o Peregrino, retornando a essa região aberta em que muitos anos atrás fora resgatado de um naufrágio por Filemon e Baucis, volta a regozijar-se com sua visão?

O Peregrino chega no final da tarde, pouco antes do "último olhar do sol" (letzten Sonnenblick), como dirá sugestivamente Filemon, e o reconhecimento da região é propiciado pelas árvores: "São as velhas tílias, sim, / No esplendor da anciã ramagem. / Torno a achá-las, pois, no fim / De anos de peregrinagem!". ${ }^{6}$ Tão logo os anciãos - primeiro Baucis, em seguida o marido - saem da cabana e o avistam, o Peregrino volta a usufruir de uma hospitalidade incondicional, que certamente reverbera aquela dispensada, num passado mítico, pelas personagens homônimas de Ovídio aos incógnitos Júpiter e Mercúrio (livro VIII das Metamorfoses). Contudo, em Goethe o idílio do reencontro irá transmutar-se poucas horas depois em quadro sinistro. Encontramo-nos então na terceira cena do ato cujo título "Noite profunda" sugere como plano de contraste um negror diante do qual as chamas destacam-se de maneira tanto mais vívida. A destruição é apresentada mediante a antiga técnica da teichoscopia, mais precisamente da perspectiva do vigia Linceu, que do alto de sua torre de observação no palácio de Fausto vê as chamas - ou os "olhares de chispas" (Funkenblicke), conforme se exprime - faiscarem em meio à "dupla noite das tílias". 
Terá Goethe se orientado, ao dar configuração definitiva a essas cenas por volta de 1830, também por acontecimentos que então se processavam, sobretudo, na Inglaterra, ${ }^{7}$ mas que aos seus olhos estavam destinados a desdobrar-se em escala mundial, ou seja, expansão industrial, crescimento econômico, mas também destruição da natureza e de antigas tradições culturais enquanto corolário inevitável do "progresso"? Se tal hipótese for razoável, seria possível proceder a uma nova leitura atualizadora dessas imagens esboçadas no último ato do drama e, à semelhança do que faz Binswanger em relação à economia moderna, relacioná-las a projetos "fáusticos" como - exemplificando apenas no âmbito da geração de energia Itaipú, Três Gargantas, no rio Yang-Tsé, ou Belo Monte, com seus extraordinários benefícios, mas também custos ambientais e humanos cuja real extensão talvez ainda esteja por se revelar? ${ }^{8}$ Essa correlação obviamente não está no texto goethiano, mas a um leitor do século XXI não seria permitido atualizá-lo à luz de experiências históricas (e, assim, de conquistas materiais e tecnológicas) de seu tempo? O velho poeta esperava, como assinalado antes, que futuros leitores pudessem vislumbrar no texto muito mais coisas do que ele pôde articular conscientemente.

De uma perspectiva hermenêutica, o enfrentamento de tais questões no interior do drama goethiano deve processar-se em consonância com o círculo de correspondências entre as partes e o todo, o que significa ter presente, no decorrer do trabalho interpretativo, o contexto amplo da "tragédia do colonizador", como se costuma designar na filologia fáustica o complexo dramático plasmado entre a primeira e a quinta cenas do último ato, mas que já se delineia em certos momentos do quarto ato. Nesse esforço hermenêutico se incluiria igualmente a tentativa de apreender a maneira pela qual as imagens esboçadas na etapa final da tragédia, sejam elas alegóricas, sejam simbólicas, se refratam e prismatizam entre si, pois por meio do procedimento de mútuos espelhamentos o velho Goethe, conforme o testemunho de uma carta de 1827, empenhava-se em revelar ao leitor atento o sentido mais profundo de sua produção literária. ${ }^{9}$

Antes de proceder a essa incursão interpretativa, que todavia não se completará nos limites deste ensaio, cumpriria indagar o porquê de se atribuírem nomes carregados de associações mitológicas a personagens envolvidas na "tragédia do colonizador", como os mencionados Baucis, Filemon e Linceu - ou ainda Helena, Eufórion e os Lêmures, que surgem no momento da morte do herói pactuário. Ou então por que deparamos com a mera designação de "Peregrino", que ecoa de maneira tão significativa na obra de Goethe? ${ }^{10} \mathrm{E}$, do lado dos perpetradores da destruição, chama a atenção que os três violentos sicários de Mefistófeles atendam por nomes que podem ser traduzidos literalmente por "Fanfarrão" (Raufebold), "Pega-Já" (Habebald) e "Agarra-Firme" (Haltefest). Mediante a rubrica cênica " $2^{\circ}$ Samuel, 23", Goethe deixa explícito que está se apoiando na passagem bíblica sobre os três valentes do rei Davi, mas ao mesmo tempo encaminhando o paralelo para uma dimensão marcada pelo paroxismo da agressividade, da ganância e da avareza, encarnadas respectivamente no jovem Fanfarrão, no adulto Pega-Já e em Agarra-Firme, já entrado nos anos. 


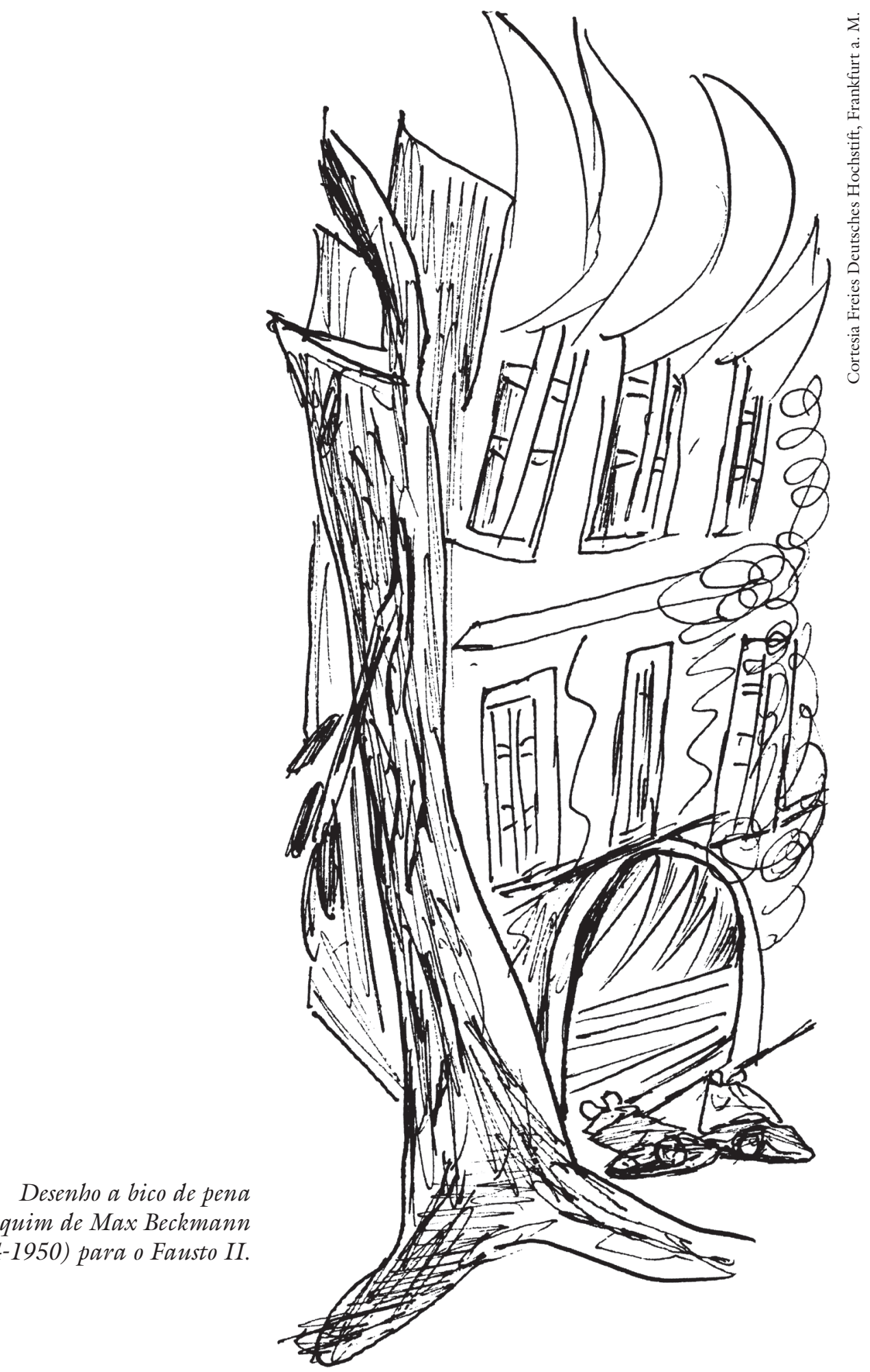

e nanquim de Max Beckmann (1884-1950) para o Fausto II.

"Mais cerimonia então não fiz, / Deles livramos-te num triz. / Não sofreu muito o par vetusto, / Caiu sem vida, já com o susto". (Mefistófeles relatando a Fausto a morte de Filemon e Baucis: versos 11.360 - 363.) 
Clássicos ou truculentamente prosaicos, esses nomes sugerem que estamos diante do processo alegórico, que o próprio Goethe, no período de sua convivência com Schiller, empenhou-se em condenar e banir dos domínios da arte. Mas por que então o poeta, em sua alta velhice, desconsidera o juízo estético proferido três décadas atrás e recorre ao procedimento que associara à redução do horizonte interpretativo e às delimitações impostas pelo "conceito", quando o "particular" (por exemplo, o jovem brutamontes Fanfarrão, que não ostenta nenhum traço mais individualizante) pouco significa em si mesmo e só vale enquanto exemplo ou ilustração para o "geral"?

Sob o ensejo de semelhantes indagações, os passos subsequentes deste ensaio propõem-se a enfocar inicialmente o contexto no qual Goethe elaborou suas concepções de símbolo e alegoria; em seguida buscará comentar alguns momentos da insólita recepção que, justamente em virtude de uma estrutura associada então ao excesso alegórico, coube ao Fausto II; por fim, estará em pauta a mudança de paradigma ocorrida com a exegese marxista que Heinz Schlaffer dedicou à Segunda Parte do drama goethiano enquanto "alegoria do século XIX".

\section{Símbolo e alegoria na concepção clássica de Goethe}

Quando Walter Benjamin, em seu estudo sobre a Origem do drama barroco alemão (finalizado em 1925 e publicado três anos depois), se lança à árdua tarefa de desfazer os preconceitos classicistas que pesavam sobre a alegoria e alçá-la ao mesmo patamar que então se reservava à dignidade estética do símbolo, ele não deixa de observar que essa visão depreciativa do procedimento alegórico derivava da "reconstrução negativa" (negative Nachkonstruktion) esboçada numa carta de Goethe a Schiller. Ter-se-ia constituído assim uma linha de pensamento que pouco depois seria retomada e aprofundada, no tocante à condenação crassa da técnica alegórica, por Schopenhauer, como evidencia a longa passagem de $O$ mundo como vontade e representação citada pelo estudioso do drama barroco. ${ }^{11}$

Posição muito diferente da benjaminiana é assumida por Georg Lukács no capítulo de sua Estética em que se debruça minuciosamente sobre essa mesma questão da alegoria e do símbolo, desde suas raízes históricas nas antigas formas ornamentais e, ainda mais remotamente, na pintura rupestre. ${ }^{12}$ Mas se essa, conforme observa o filósofo húngaro, não pode ser pensada fora das finalidades mágicas (ligadas, sobretudo, à caça) que lhe deram origem, a partir do momento em que a arte conquista para si o impulso mimético autônomo, a alegoria é compelida a associar-se, de maneira inextricável, a tendências desantropomorfizantes, as quais a alienam da imanência histórica e engendram sua subserviência à religião, que nas vanguardas do século XX seria substituída pela transcendência do "Nada". Por outro lado, à arte simbólica (e, para Lukács, também realista) não teria restado senão empreender ao longo dos séculos uma "tática de guerrilha" para emancipar-se desses domínios alheios à esfera estética, segundo se revelaria com mais clareza no movimento que conduz da Idade Mé- 
dia - enfocada, sobretudo, à luz das obras de Dionísio Areopagita, Joaquim de Fiori e Dante - ao Renascimento. Nessa polêmica linha argumentativa, pouco resta do momento de protesto que Benjamin vislumbrou na facies hippocratica da alegoria, interpretada enquanto denúncia de tudo aquilo que a história tem desde o início de "extemporâneo, sofrido, fracassado".

Longe, portanto, de compartilhar a concepção benjaminiana, Lukács vê a alegoria sempre restrita aos limites do fetichismo e da alienação: apresenta-nos assim, na longa história da reflexão teórica sobre o procedimento alegórico (que remonta, pelo menos, a Quintiliano), sua condenação mais crassa e inconciliável. Mas haveria legitimidade em erigir a figura de Goethe, como faz o autor de A destruição da razão, enquanto patrono dessa cruzada antialegórica, a qual se estende, nas últimas páginas do estudo, às obras de Stéphane Mallarmé, James Joyce, Gottfried Benn e de outros adeptos do "divertissement do melancólico", de acordo com a expressão tomada ao próprio Benjamin?

De qualquer modo, vale assinalar que, embora Goethe ocupe posição fulcral na argumentação de ambos os teóricos, nenhum deles se deu ao trabalho de problematizar a condenação goethiana da alegoria à luz de procedimentos literários mobilizados na Segunda Parte do Fausto. Ou será que não nos encontramos propriamente no terreno alegórico quando Mefistófeles, municiando-se para entrar na guerra civil do quarto ato, refere-se aos seus três sequazes, recrutados de domínios abstratos e quiméricos para lutar ao lado das forças imperiais, como "turba alegórica" (v.10.329)? Ou quando o Mancebo-Guia, quase cinco mil versos antes, não apenas se refere a si e a seu acompanhante Pluto enquanto "alegorias", mas também exige serem reconhecidos como tais (v.5.531)? Se no primeiro caso o significado das personagens já se revela nos nomes (nomen est omen parece vigorar em larga medida para figuras alegóricas), no último deparamos com a alegoria da poesia, conforme explicita o próprio Mancebo-Guia ("Eu sou o Pródigo, a Poesia, / Meus bens esbanjo; sou o Poeta, / Que em derramar dons se completa", v.5.573), preparando assim, numa referência antecipatória que causou perplexidade a Eckermann, a aparição igualmente alegórica de Eufórion na última cena do terceiro ato. ${ }^{13}$

Ao conceber essas personagens (e outras que povoam o Fausto II), não terá Goethe procedido em consonância com o modo alegórico, ou seja, não terá buscado o "particular" apenas para expressar o "geral", no caso a prodigalidade da poesia ou a violência que acompanhará pari passu o projeto fáustico de colonizar espaços conquistados ao mar? Pois dificilmente se poderá dizer, quanto a essas passagens, que o poeta tenha vislumbrado ou enxergado de maneira intuitiva - schanen no original, afim ao verbo latino intueri (e ao substantivo intuitio - o geral no particular, como se pode ler na sentença de número 751 no volume Máximas e reflexões: ${ }^{14}$

Faz uma grande diferença se o poeta busca o particular para expressar o geral ou se ele enxerga o geral no particular. Naquele caso origina-se a ale- 
goria, quando o particular só vale como ilustração, como exemplo do geral; o último caso, porém, constitui a verdadeira natureza da poesia: ela exprime um particular sem pensar no geral ou sem indicá-lo. Contudo, aquele que capta de maneira viva esse particular, apreende ao mesmo tempo o geral, sem se dar conta disso ou só mais tarde se dando conta.

Conceber uma personagem, um objeto ou acontecimento apenas com a finalidade de ilustrar um conceito geral leva, na perspectiva do Goethe clássico, a uma limitação drástica das possibilidades interpretativas em relação à imagem, segundo a formulação da sentença anterior (750):

A alegoria converte o fenômeno em um conceito, converte o conceito em uma imagem, de tal modo que o conceito, na imagem, será sempre apreendido de maneira limitada, completa e será sempre expresso nos limites dessa imagem.

E no polo oposto teríamos o símbolo, celebrado por Goethe na sentença 749 enquanto "verdadeira natureza da poesia":

O procedimento simbólico converte o fenômeno em ideia, a ideia em uma imagem, e de tal modo que a ideia, na imagem, permanece sempre infinitamente ativa e inatingível, e mesmo pronunciada em todas as línguas, permanece contudo inexprimível.

Se é verdade que essas sentenças foram publicadas somente em 1824 na revista Über Kunst und Altertum [Sobre Arte e Antiguidade] - numa época, portanto, em que o poeta parecia inclinar-se cada vez mais para o procedimento alegórico - a sua redação deu-se muito provavelmente por volta de 1797 , remontando às intensas discussões estéticas que travava então com Friedrich Schiller. É o que se depreende das palavras que abrem a sentença 751 e contextualizam a diferenciação acima citada:

Minha relação com Schiller se baseava na orientação decidida de ambos para uma meta; nossa atividade comum, na diversidade dos meios através dos quais aspirávamos alcançar aquela meta.

Por ocasião de uma delicada diferença que certa vez aflorou entre nós e à qual sou novamente remetido agora por um trecho de sua carta, desenvolvi as considerações que vêm a seguir.

Não seria o caso de tentar esmiuçar agora essa "delicada diferença" (zarte Differenz) a que Goethe alude de maneira algo diplomática. ${ }^{15}$ De todo modo, a diferença também se faz sentir no estudo sobre Poesia ingênua e sentimental que Schiller publica em 1795 e no qual Goethe é associado em larga escala ao tipo "ingênuo", que não busca a natureza mas já éa própria, enquanto o próprio autor se compreendia no polo "sentimental", com sua tendência filosofante e dedutiva, partindo do "geral" para o "particular" e percorrendo assim trajetória inversa à do poeta ingênuo. Todavia, ao contrário da concepção goethiana de símbolo e alegoria, a tipologia de Schiller não estabelece hierarquia entre as atitudes ingênua e sentimental, pois ambas seriam igualmente válidas para se alcan- 
çar a meta perseguida pelo poeta. No caso de se querer forçar uma aproximação entre as tipologias dos dois clássicos, talvez se possa dizer que o "simbólico" tende a estar próximo do "ingênuo" enquanto o "alegórico" encontra antes suas afinidades com o "sentimental". Seria, no entanto, um passo temerário, pois o que se tem de fato é que Schiller, embora inclinado a pensar em termos antitéticos, como se evidencia já no título do estudo, jamais empregou em seus escritos a diferenciação goethiana entre símbolo e alegoria, o que pode ser indício de discordância. ${ }^{16} \mathrm{E}$, por outro lado, uma das razões que podem ter levado Goethe a publicar as sentenças sobre símbolo e alegoria em 1824, cerca de três décadas após as discussões com o amigo falecido em 1804 e, sobretudo, num momento em que sua própria práxis poética aparentemente já não correspondia mais àquelas formulações, foi o impulso de contrapor-se a tendências românticas que tinham no pensamento de Schiller e, em especial, no tratado sobre Poesia ingênua e sentimental um significativo ponto de apoio. ${ }^{17}$

Para além, contudo, dessa longa defasagem entre a concepção e a publicação das sentenças sobre símbolo e alegoria, não deixa de ser surpreendente verificar que o trecho mais alegórico do Fausto I date justamente do ano 1797, quando Goethe formula sua drástica condenação desse mesmo procedimento e a consequente valorização do simbólico. Trata-se da cena "Sonho da Noite de Valpúrgis ou As Bodas de Ouro de Oberon e Titânia”, que entra na tragédia como um intermezzo que de certa maneira veio ocupar o lugar da segunda parte da "Noite de Valpúrgis", o culto orgiástico a Satã suprimido da versão canônica. ${ }^{18}$ Redigida com intermitências entre 1797 e 1805, a própria "Noite de Valpúrgis" está povoada por não poucos personagens alegóricos, a exemplo dos nostálgicos representantes do Ancien Régime que Mefisto encontra reunidos em torno de "brasas meio extintas": figuras designadas apenas por "General", "Ministro", "Parvenu", “Autor". No intermezzo, todavia, a alegoria experimenta tal intensificação e prevalece de maneira tão irrestrita que o leitor (ou espectador) pode legitimamente sentir-se incomodado em ter de ouvir semelhante profusão de mensagens cifradas, proclamadas por figuras apresentadas como "Viajante curioso", "Cata-vento", "Gênio em vias de formação", "Estrela-cadente" etc. Não por acaso, foi do esteta Friedrich Theodor Vischer, que com muita mordacidade criticou e parodiou a estrutura alegórica do Fausto II, que partiu a condenação mais veemente do "Sonho da Noite de Valpúrgis": "O conjunto é uma interpolação de palha satírica num poema eterno, um ato que se deve considerar como leviandade irresponsável", observava Vischer em 1875 nos seus "Novos subsídios para a crítica do poema".

Seja como for, essa incômoda "interpolação" constitui uma exceção na Primeira Parte da tragédia e fora da ominosa montanha (Brocken) na região do Harz, que oferece o palco para a "Noite de Valpúrgis" e seu "Sonho", a alegoria se manifesta de maneira mais concentrada apenas na "Cozinha da bruxa", também um espaço demoníaco carregado de sugestões absurdas e irracionais. Vemos aqui, entre abstrusidades como a famosa "tabuada da bruxa", cerco- 
pitecos brincando com uma bola (na verdade, uma frágil esfera de barro) de inequívoco significado alegórico: "É assim o mundo; / Sobe e cai, fundo, / Sem pausar, rola; / Qual vidro soa, / Que quebra à toa!". Logo em seguida, é o próprio Mefisto que, com os olhos voltados aos acontecimentos que se processavam na França revolucionária, entra no jogo alegórico: senta-se numa poltrona apresentada como "trono real", designa de "cetro" o abano que tem em mãos e exprime o desejo pela "coroa", a qual é providenciada de imediato pelos macacos - mas essa já vem rachada e, assim o exige a lógica alegórica, não demora a se partir de vez.

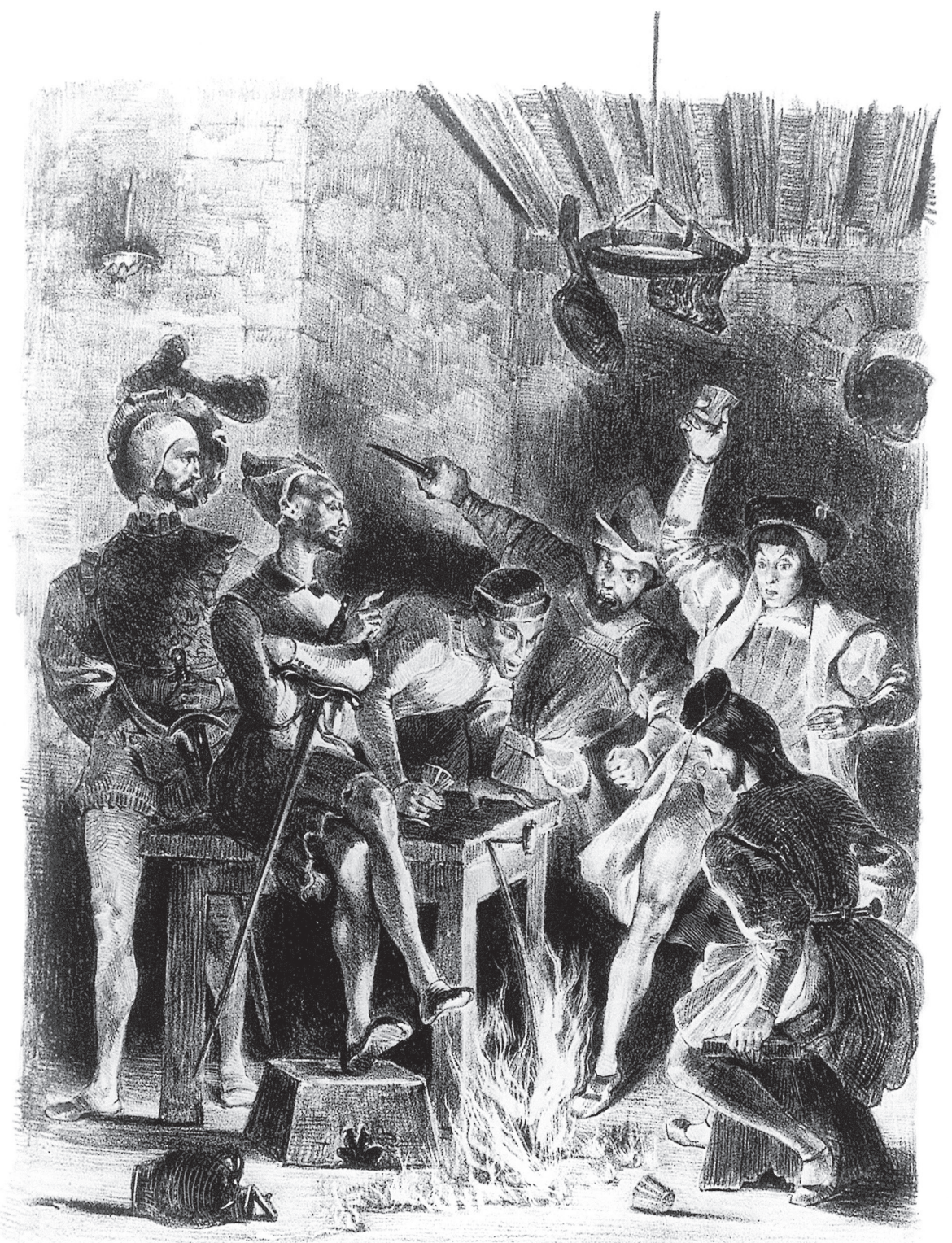

Ilustração de Eugène Delacroix (1798-1863) para a cena "Na Taberna de Auerbach", retomada e concluida por Goethe (como a cena "Cozinha da Bruxa”) após a Revolução Francesa. 
Considerando que a cena em questão foi redigida em 1788, durante a estada de Goethe em Roma, e os versos alusivos aos acontecimentos parisienses do ano seguinte (como os de Mefisto: "Num trono estou, como o rei em pessoa; / O cetro tenho aqui, só me falta a coroa") constituem um adendo para a publicação, em 1790, de Faust. Ein Fragment, evidencia-se que Goethe buscou inserir a Revolução Francesa na atmosfera de desvario que reina nessa "Cozinha da bruxa". ${ }^{19}$ Desse modo, a cena pode ser interpretada, em seu conjunto, enquanto alegorização das forças irracionais que, aos olhos do poeta, manifestam-se no processo histórico, incluindo-se o acontecimento capital da era burguesa - numa perspectiva, portanto, que se pode considerar muito distante daquela oferecida pela filosofia hegeliana da história, em que a marcha do mundo (Weltlauf) aparece governada pela razão e, por conseguinte, racionalmente compreensível. ${ }^{20}$

"A história, mesmo a melhor de todas, sempre tem algo de cadavérico, o odor de criptas", lê-se numa nota redigida para a autobiografia Poesia e verdade, e em 1829 o octogenário dizia as seguintes palavras ao seu amigo (e chanceler do Grão-Ducado Saxônia-Weimar-Eisenach) Friedrich von Müller: "Eu não cheguei a idade tão avançada para me preocupar com a história do mundo, que é a coisa mais absurda que existe; para mim é indiferente se fulano ou sicrano morre, se desaparece esse ou aquele povo; eu seria um tolo se fosse me importar com isso". No entanto, há também não poucas declarações de Goethe que revelam intensa, até mesmo exasperada preocupação com a "história do mundo", como se depreende, por exemplo, das palavras registradas mais uma vez pelo chanceler von Müller pouco depois da eclosão da revolução parisiense de julho de 1830 : "A impressão que essa revolução-relâmpago causou por aqui é indescritível. Não tivemos nenhuma crise maior do que esta. Goethe diz que ele só consegue acalmar-se mediante a consideração de que ela representa o maior exercício de reflexão (größte Denkübung) que lhe coube no final da vida".

Vista em conjunto, a relação de Goethe com a história mostra-se demasiado complexa para ser reduzida apenas a uma dimensão negativa e, consequentemente, à atitude de rejeição que se observa nas duas declarações acima. O mais expressivo testemunho dessa complexidade oferece-nos a Segunda Parte da tragédia, sobretudo as cenas do quinto ato cuja estrutura, aparentemente alicerçada sobre procedimentos alegóricos, faz o conceito de progresso, de utopia social, aparecer sob o signo de inextricável ambivalência. Mas no geral essa percepção não foi possível às primeiras gerações de leitores do Fausto II e só começou a articular-se muito tempo após sua publicação no final de 1832 .

\section{Pedra de escândalo alegórica}

Entre as inúmeras retomadas do assunto fáustico posteriormente a Goethe encontra-se a novela epistolar Fausto (1856) de Ivan Turgueniev, que traz como epígrafe o verso pronunciado pelo doutor pouco antes do pacto com Mefisto: "Deves privar-te, só privar-te!" (v.1.549). Na quarta das nove cartas que compõem a obra russa, o narrador reconstitui as circunstâncias em torno da leitura 
que faz da Primeira Parte da tragédia goethiana a um pequeno círculo de pessoas. "Eu lia apenas para Vera Nikolaevna", escreve o narrador a um amigo: "Uma voz interior dizia-me que o Fausto lhe causava funda impressão". Contudo, para não enfraquecer o impacto da leitura, o narrador diz também ter omitido o intermezzo do "Sonho da Noite de Valpúrgis", pois “em sua estrutura essa cena já pertence à Segunda Parte; e também deixei de lado alguns dos trechos noturnos no monte Brocken".

Não é difícil perceber que a exclusão operada pelo narrador atingiu justamente as passagens mais alegóricas do Fausto I e que, portanto, sequer terá entrado em sua cogitação apresentar à mulher amada qualquer cena da continuação da tragédia. Subjaz assim à novela fáustica de Turgueniev (também ela uma trágica história de amor, como indiciado pela epígrafe) um ponto de vista que concede irrestrita primazia à obra de 1808, considerada no geral mais acessível e comovente do que os "gracejos muito sérios" da Segunda Parte, que Goethe não quis ver publicados em vida.

Quando esses vieram a lume alguns meses após a morte do poeta, um de seus primeiros críticos, Karl Rosenkranz (discípulo e primeiro biógrafo de Hegel, também sucessor de Kant em Königsberg), prognosticava com extraordinária acuidade que o Fausto II "jamais alcançará a popularidade da Primeira Parte, jamais encantará, do mesmo modo como esta, a nação", uma vez que atinge muito mais a "reflexão" do que o "sentimento". Todavia essa resenha pioneira de Rosenkranz avulta como notável exceção entre as posições que constituíram a recepção contemporânea da tragédia, marcada principalmente por recusas, condenações e até mesmo pilhérias. Lembrem-se, por exemplo, as escarnecedoras palavras que o crítico Wolfgang Menzel (possivelmente o mais contumaz detrator de Goethe) pronunciou sobre a cena final do Fausto II, cuja coreografia em torno da Virgem Maria, de Gretchen e de três outras célebres penitentes é comparada com a "a corte de uma alegre rainha", tal como a "sociável Maria Antonieta":

Vemos ao seu redor apenas damas da corte e pajens como anjos mais e menos graduados; na entrada, alguns místicos em adoração como porteiros devotos. E então o velho pecador é introduzido [...] é bonito, uma jovem dama da corte intercede em seu favor, a rainha celestial sorri e - a sinecura no céu é toda sua. - Onde fica Deus? Será que não há mais nenhum homem no céu?

Já o acima mencionado Friedrich Theodor Vischer, após esboçar num texto de 1861 o que seria um enredo mais substancial - e, no seu entender, mais "digno" - para a Segunda Parte da tragédia, parodia a estrutura alegórica do Fausto II numa peça publicada no ano seguinte: A Terceira Parte da Tragédia, acrescida do subtítulo Poetizada fielmente no espírito da Segunda Parte do Fausto goethiano por Deutobold Symbolizetti Allegoriowitsch Mystifizinsky. ${ }^{21}$

Mas também artistas do nível de Franz Grillparzer ou Heinrich Heine - de resto, grandes admiradores de Goethe - manifestaram-se nesse mesmo diapasão. 
Enquanto o poeta e dramaturgo austríaco observava que a Segunda Parte do Fausto teria sido muito mais "redigida" com o intelecto do que "poetizada", Heine se refere a ela, no posfácio ao seu Doutor Fausto. Poema coreográfico como "paralítica das coxas" (lendenlahm, também com a conotação de "impotente", pois Lende significa a região das coxas e partes sexuais). Somente o ato em torno da união entre Fausto e Helena mostra-se digno de louvor para Heine, pois Goethe teria tratado con amore a bela representante da Antiguidade grega:

É o que há de melhor, ou antes, é a única coisa boa nessa Segunda Parte, nesse tremedal labiríntico e alegórico, onde, entretanto, levanta-se de repente, sobre sublime pedestal, uma imagem grega maravilhosamente consumada em mármore, a qual nos mira com seus alvos olhos de maneira tão encantadora, tão divinamente pagã que por pouco a melancolia não nos domina por completo. Trata-se da estátua mais deliciosa que jamais saiu do ateliê goethiano e custa a acreditar que tenha sido talhada pelas mãos de um ancião.

Se Heine, todavia, deixou fora de sua mordacidade o terceiro ato, que o próprio Goethe caracterizou como "fantasmagoria clássico-romântica", o dramaturgo e poeta Friedrich Hebbel não abriu nenhuma exceção na drástica condenação que registra em seu diário em setembro de 1845: "Na Segunda Parte do Fausto, Goethe faz tão somente suas necessidades fisiológicas".

Fora da Alemanha as reações a essa Segunda Parte não foram muito diferentes e nem de longe a insólita continuação da tragédia - como acima delineado à luz da novela epistolar de Ivan Turgueniev - aproximou-se do prestígio alcançado pela Primeira Parte. Machado de Assis oferece expressivo testemunho dessa recepção, pois é exclusivamente do texto publicado por Goethe em 1808 que retirou a totalidade de suas inúmeras alusões e referências a Fausto e Mefistófeles, "o espírito que nega" (como se lê no conto "A Igreja do Diabo"). Ainda no âmbito linguístico do português, vale lembrar as drásticas palavras com que Antonio Feliciano de Castilho, cuja tradução do Fausto I deflagraria em Portugal a célebre e virulenta "Questão do Fausto", fundamenta sua decisão de não aventurar-se pela Segunda Parte, o que seria "um trabalho ainda mais fragoso", pois tantos e tão crespos são no último Fausto os enigmas filosóficos, tão abstruso o senso das ficções, e as ficções mesmas tão desnaturais, tão inverossímeis, tão impossíveis (ia-me quase escapando tão absurdas) que o bom gosto e o bom senso, que tão benévolos perdoaram e receberam a lenda velha do Dr. Fausto, não sei como se haveriam com o Fausto último. O primeiro, o nosso, foi um gigante; o último figura-se ao espírito da nossa consciência o homúnculo, um produto abusivo das forças da arte..$^{22}$

Essa apreciação contaria certamente com o respaldo de Wolfgang Menzel, Friedrich Theodor Vischer, Friedrich Hebbel, assim como de outros nomes acima citados. Para não ter de ouvir semelhantes julgamentos e ver-se exposto à incompreensão e mesmo zombarias de seus contemporâneos, o velho poeta permaneceu firme no propósito de não publicar em vida os "gracejos muito sérios" 
do Fausto II, conforme se exprimiu, cinco dias antes da morte, na célebre carta a Wilhelm von Humbold. Não queria ver os esforços despendidos ao longo de décadas em prol de sua "insólita construção" poética, ainda citando as metáforas que assomam na carta, desmembrados e "arrastados à praia, onde ficariam como destroços de naufrágio para logo serem soterrados pelas dunas das horas". ${ }^{23}$

Considerando que o prognóstico goethiano se revelou de fato procedente, de onde o poeta terá extraído a convicção de que o horizonte de expectativa contemporâneo não dispensaria ao Fausto II a acolhida que coube à Primeira Parte - ou ainda ao romance Os anos de aprendizado de Wilhelm Meister (de imediato saudado por Friedrich Schlegel como uma das três grandes tendências da época), para não falar do Werther, talvez o maior sucesso literário de todos os tempos? De certo modo a resposta a essa questão tem a ver com a questão do "símbolo" e "alegoria", e se considerarmos, por exemplo, que Hegel proferiu rigorosa condenação do procedimento alegórico em sua Estética, mas saudou o "fragmento" do Fausto publicado em 1790 como "tragédia filosófica absoluta", então podemos talvez relacionar aquele prognóstico goethiano à percepção de que o Fausto II de modo algum corresponderia à então hegemônica estética do símbolo. ${ }^{24} \mathrm{E}$ já que essa encontrava sólidos alicerces justamente em concepções elaboradas durante o classicismo de Weimar, pode-se inferir que pressupostos decisivos para a constituição de um horizonte de recepção desfavorável à Segunda Parte da tragédia foram fornecidos paradoxalmente pelo próprio Goethe.

\section{Mascherate Carnascialesche}

"Pois que somos alegorias e assim tens de nos reconhecer": com essas palavras o Mancebo-Guia exorta o Arauto, na longa cena do desfile carnavalesco no Palatinado Imperial, a anunciar de modo apropriado a aparição da fantasmagórica carruagem que, puxada por quatro animais alados e trazendo no alto as alegorias do deus da riqueza e da avareza, irrompe na sala do entrudo em "tempestuoso assalto". Até então haviam desfilado máscaras conhecidas do Arauto, sejam as do carnaval florentino no tempo de Lorenzo de' Medici - extraídas, sobretudo, da obra de Grazzini (1750) Tutti i Trionfi, carri, mascherate o Canti carnascialeschi - ou da mitologia grega (Graças, Parcas, Fúrias), ou ainda fantasias passíveis de desvendamento, como a Sagacidade que surge sobre um elefante (alegoria do trabalho físico) flanqueado pelo Medo e pela Esperança esses, todavia, devidamente "acorrentados", pois em seu todo o bloco alegoriza o poder estatal governado pela razão. Mas agora entram em cena figuras não previstas no roteiro carnavalesco, as quais reagem à perplexidade do Arauto com a exigência, explicitada pelo condutor da carruagem, de serem compreendidas enquanto alegorias.

$\mathrm{Na}$ filologia goethiana ao longo dos séculos XIX e XX ninguém correspondeu com tanto empenho a essa reivindicação quanto Heinz Schlaffer, que em seu estudo da Segunda Parte da tragédia como "alegoria do século XIX" (na formulação do subtítulo) não apenas submete a mascarada carnavalesca do pri- 
meiro ato a uma cerrada interpretação marxista, como também estende os resultados aí alcançados ao conjunto do Fausto II, uma vez que nessa cena particular ("Sala vasta com aposentos contíguos") se anunciariam, de seu ponto de vista, os temas que irão dominar os quatro atos subsequentes. Ao lado da mencionada exortação do Mancebo-Guia ao reconhecimento alegórico, a interpretação de Schlaffer privilegia o verso em que o Arauto, assustando-se com a multidão que avança sobre as riquezas que jorram da carruagem, solicita a intervenção de Pluto, chamando-o de "embuçado" e "herói mascarado" (v.5.737). Essas palavras possibilitariam, na perspectiva do intérprete, o estabelecimento de uma relação com a análise da sociedade capitalista empreendida por Karl Marx no Capital, de maneira mais particular com a constatação, formulada no segundo capítulo, de que as "máscaras de personagem" (Charaktermasken) assumidas pelos indivíduos que integram essa sociedade não seriam outra coisa senão personificações de relações econômicas e de interesses de classe. E uma vez que a análise de Marx se vale de uma linguagem fortemente imagética, que não raro envereda também por personificações alegóricas (por exemplo, na passagem em que fala do encontro fecundante entre Monsieur le Capital e Madame la Terre ${ }^{25}$ ) - esse fato apenas reforçaria, na visão de Schlaffer, os vínculos entre a Segunda Parte do Fausto e O capital. Desse modo, seria justamente a forma literária da alegoria que enseja tal aproximação, pois suas estruturas significativas corresponderiam, já na visão do velho Goethe, às "determinações essenciais da moderna sociedade burguesa": suspensão de todo elemento concreto-sensual, dissolução de contextos naturais, criação de um mundo artificial, incongruência entre forma aparente e significado, funcionalização de objetos em meros atributos, enfraquecimento da individualidade, predomínio de abstrações. ${ }^{26}$

Para Schlaffer um primeiro lampejo, ainda inteiramente intuitivo, dessa nova configuração social teria ocorrido a Goethe durante a visita que fez à sua cidade natal em 1797, conforme se exprime na carta que dirige a Schiller no dia 16 de agosto. Surpreendentemente os objetos de sua percepção durante a estada em Frankfurt lhe infundem "uma espécie de sentimentalidade" (eine Art von Sentimentalität), como observa em alusão à categoria teorizada pelo amigo no tratado sobre Poesia ingênua e sentimental, e pergunta em seguida se não se trataria de uma "disposição poética" provocada por coisas e objetos não inteiramente poéticos. Após tê-los observado mais detidamente, continua Goethe, ele acredita poder afirmar que tais coisas e objetos

são simbólicos, ou seja, são casos eminentes que surgem, em característica variedade, como representantes de muitíssimos outros, abarcam em si uma certa totalidade, requerem uma sequência, suscitam em meu espírito sensações afins e dessemelhantes e, desse modo, levantam a reivindicação interior e exterior por uma determinada unidade e completude.

As considerações teóricas são exemplificadas à luz da antiga casa de seu avô, mais exatamente da valorização que experimentara com seu pátio e jar- 
dim após ter sofrido o impacto de bombardeios franceses. O espaço patriarcal e limitado em que vivera outrora um velho alcaide de Frankfurt - isto é, o seu avô materno Johann Wolfgang Textor (1693-1771) - converte-se então, graças à ação de homens astutos e empreendedores, num centro em que se compra e vende toda sorte de mercadorias e produtos, portanto sobremaneira útil para a cidade, como assinala o visitante. $\mathrm{E}$ a seus olhos parece tratar-se de um processo em contínuo desdobramento:

O estabelecimento foi arrasado por singular acaso durante o bombardeio e vale agora, em grande parte como um amontoado de escombros, o dobro da quantia que há onze anos foi paga pelos atuais proprietários aos meus parentes. Considerando-se que o conjunto possa ser mais uma vez comprado e reformado por um novo empreendedor, você percebe então facilmente que em mais de um sentido ele tem de surgir perante minha visão, de modo especial, como símbolo de muitos milhares de outros casos nessa cidade tão rica em comércio e negócios. ${ }^{27}$

Embora a palavra "símbolo", representante de incontáveis “outros casos”, desponte de modo explícito duas vezes na carta, toda a argumentação de Schlaffer se desenvolve no sentido de demonstrar que o conceito que corresponderia de fato ao espanto de Goethe diante da paradoxal valorização da antiga propriedade familiar seria antes o de "alegoria”. Pois o que estaria em jogo na observação comunicada a Schiller é, antes de tudo, um fenômeno abstrato, ou seja, fundamentado muito mais na dissociação e incongruência entre aparência sensível (a casa bombardeada e em ruínas) e significado (a valorização imobiliária) do que na concretude simbólica que estabeleceria laços coerentes entre esses dois polos e os manteria numa correlação viva e interativa. Sendo assim, na leitura de Schlaffer a carta de Goethe se destaca precisamente por uma curiosa "lacuna" - a lacuna da alegoria, que só começaria a ser preenchida muitos anos depois, já em pleno século de Baudelaire.

Mas será mesmo lícito enxergar no fenômeno imobiliário constatado por Goethe um potencial alegórico de tal alcance que se possa considerar o Fausto II como a concretização tardia da possibilidade estética (isto é, alegórica) surgida em 1797? Deixando em aberto essa questão, o que se pode afirmar é que Heinz Schlaffer se utiliza dessa carta para apertar as malhas de uma rede exegética lançada sobre o conjunto da obra, forçando-a dessa maneira a entrar en bloc num espartilho teórico que começa a ser urdido, na primeira parte do estudo ("Pressupostos"), mediante a discussão (aprofundada e competente, deve-se assinalar) de reflexões sobre a alegoria desenvolvidas por nomes como Hegel, Herder, Lessing, Moritz e Schopenhauer, ao que se segue um último subcapítulo enfocando o emprego de personificações e expressões alegóricas no Capital.

Uma vez estabelecidos esses "pressupostos" teóricos, a análise passa a dissecar então a estrutura compactamente alegórica, conforme entende o autor, do texto goethiano, e não apenas a partir do desfile das alegorias carnavalescas 
na "Sala vasta", mas começando já com a cena "Região amena”, o prólogo que mostra a recuperação de Fausto, depois da tragédia de Margarida, em meio a um majestoso quadro da natureza. Mas qual seria o teor efetivo dessa cena de abertura? Após a regeneração física e espiritual proporcionada pelo sono sob influxos benfazejos, Fausto desperta e logo fixa o olhar no sol nascente; todavia, o ofuscamento o faz voltar-se para o arco-íris que se desprende de uma queda-d'água. Isso é relatado por meio de um monólogo na estrutura rímica de tercinas, o qual se fecha com a proposta de enxergar no arco-íris o reflexo ou refração (Abglanz) de toda aspiração humana: "Vês a ânsia humana nele refletida; / Medita, e hás de perceber-lhe o teor: / Temos, no reflexo colorido, a vida". Essas imagens reverberam a concepção goethiana, que aflora em vários momentos de sua obra, de que ao ser humano só é possível um conhecimento indireto do "verdadeiro", sob a mediação, portanto, do "reflexo", da refração - ou ainda, como dizem os dois primeiros versos do Chorus mysticus, do "símile" (Gleichnis).

Em sua "devoção mundana" ( Weltfrömmigkeit, neologismo de inspiração panteísta cunhado no romance Os anos de peregrinação de Wilhelm Meister), Goethe identificou por vezes esse "verdadeiro" ao que transcende a existência terrena, e num texto de 1825 leem-se as palavras: "Nós o contemplamos [o verdadeiro] apenas como reflexo, como exemplo, símbolo, em fenômenos particulares e afins. Nós o percebemos como vida incompreensível e, contudo, não podemos renunciar ao desejo de compreendê-lo. Isto vale para todos os fenômenos do mundo apreensível". Mesmo que essa concepção goethiana possa parecer abstrusa a certos leitores, ela desempenha aqui um papel fundamental e não seria lícito negligenciá-la se o objetivo é atingir uma compreensão adequada da cena "Região amena". No entanto, Schlaffer enxerga nas imagens de abertura do Fausto II tão somente o anúncio de um programa estético que, ao contrário do que ocorre na Primeira Parte da tragédia, irá privilegiar maciçamente a representação indireta por meio de enigmas e conceitos (portanto, em chave alegórica), de tal modo que o verso conclusivo do monólogo - “Temos, no reflexo colorido, a vida" - poderia ser colocado como epígrafe à obra toda:

Assim é mostrado ao espectador, de modo exemplar, como ele deve comportar-se perante os fenômenos enigmáticos que a obra manipula no mais alto grau. Da mesma maneira como sol, cascata e arco-íris refletem aqui a "aspiração humana”, todas as imagens subsequentes são dispostas em função de significados e mostram-se carentes de exegese. [...] Numa tal dissociação poética e relação abstrata entre construção imagética e interpretação conceitual está exposta a estrutura da alegoria, ainda antes de se iniciar o efetivo desfile das alegorias. (op. cit., p.68)

A imagem do arco-íris enquanto "reflexo colorido" de um astro que não pode ser encarado diretamente mostra-se, no contexto da cena em questão, muito mais simbólica do que alegórica, ainda que venha acompanhada de um comentário explicitando o seu significado. Se o intérprete entende esses versos apenas enquanto programa estético ou como espécie de arquitrave conceitual 
das alegorias que começam então a desfilar em sucessão ininterrupta pelos mais de sete mil versos subsequentes, não estará ele construindo um proton psendos com implicações para o conjunto do estudo? Uma das consequências dessa perspectiva exegética é colocar lado a lado, na suposta série alegórica que atravessa todos os atos da tragédia, elementos que dificilmente poderiam ser nivelados, conforme se verifica na observação de que "quase tudo que acontece e entra em cena nessa obra é apresentado expressamente como invenção artificial e técnica: máscaras, flores artificiais, papel-moeda, Helena, Homúnculo, vitórias militares, novas terras". Hipertrofia-se desse modo o motivo das flores artificiais apregoadas pelas jardineiras que constituem o primeiro bloco carnavalesco (motivo que, de resto, Goethe encontrou já na mencionada obra de Grazzini sobre o carnaval florentino) e esse detalhe, como outras máscaras carnavalescas que se apresentam na cena "Sala vasta" (inclusive as próprias jardineiras), assoma em pé de igualdade com o projeto econômico, engendrado por Mefistófeles, de implementação do papel-moeda ou com o complexo dramático da colonização que domina as cinco primeiras cenas do quinto ato.

Distanciar-se, contudo, desse nivelamento operado pela interpretação de Schlaffer não significa reduzir a importância da cena "Sala vasta", que comporta outras possibilidades de leitura que mal entram em seu campo de visão maciçamente fixado na representação alegórica. Uma dessas possibilidades seria vislumbrar nas imagens carnavalescas a configuração típica (ou "fórmula ético-estética", expressão que substituirá os termos "símbolo" e "alegoria" na linguagem do velho poeta) de um estado social imerso em grave crise, mas cuja elite se compraz em executar a chamada "dança sobre o vulcão", como se costuma dizer da corte francesa em torno de Maria Antonieta às vésperas da Revolução. Pois Goethe faz o entretenimento carnavalesco assomar também como espécie de evasão ou recalque de uma situação caracterizada na cena imediatamente anterior: estagnação econômica, corrupção generalizada, justiça arbitrária e venal, prevalência dos interesses particulares, dilapidação dos recursos públicos, motins e desordens que já anunciam a guerra civil que engolfará o país no quarto ato. Em face desse sinistro quadro o Imperador e os cortesãos (a elite dessa sociedade) anseiam entregar-se com ímpeto tanto maior aos festejos do entrudo, o que enseja o sagaz comentário de Mefistófeles: "Que o mérito e a fortuna se entretecem, / Em tontos desses é ideia que não medra; / E se a pedra filosofal tivessem, / Ainda o filósofo faltava à pedra".

Mas enveredar por essa alternativa de leitura da cena "Sala vasta" significaria reconhecer-lhe um significado mais autônomo, que seria pouco compatível com uma abordagem que tende a nivelar os diversos elementos do enredo dramático por força da constatação de que "quase tudo que acontece e entra em cena nessa obra é apresentado expressamente como invenção artificial e técnica", ou seja, submetido às estruturas da forma alegórica. Nesse sentido, outro questionável nivelamento operado pela perspectiva de Schlaffer envolve a aparição 
das "quatro mulheres grisalhas" que se autodenominam Penúria, Insolvência, Privação e Apreensão, das quais apenas a última consegue penetrar no palácio de Fausto. Temos aqui uma das cenas mais impressionantes de toda a tragédia, mas que no estudo em questão é constrangida ao mesmo patamar de certos momentos do carnaval. Como se dá essa equivalência? Seu ponto de partida reside na constatação de que as performances e relações alegóricas deflagradas no entrudo significam ao mesmo tempo o fim do mundo feudal e o advento do sistema capitalista. A afirmação mostra-se em si plenamente convincente e o crítico a desdobra em expressivas formulações: "Com a licença do carnaval a corte encena aquilo que virá depois dela. O entrudo carnavalesco é o sonho que uma época que chega ao fim tem da época vindoura". Mas, em seguida, dá-se o questionável salto, por cima de mais de seis mil versos, para a cena "Meia-noite", e precisamente por meio de uma abordagem das alegorias "negativas" do desfile na sala vasta (Poeta satírico, Parcas, Fúrias, Avareza, Zoilo-Tersites e algumas outras), às quais Goethe teria delegado a função de apontar desde logo para os limites e crises das potências burguesas emergentes, como dinheiro, lucro, mercado, trabalho. Desse modo, elas manteriam presente tudo aquilo que se subtrai às promessas de felicidade da "prosperidade econômica", o que se manifesta no decurso do desfile carnavalesco enquanto discórdia, insatisfação, remorso ou destruição, como o incêndio que, atingindo a barba postiça do Imperador fantasiado de Pã, põe fim ao divertimento da corte em meio à desastrosa conjuntura econômica e política do reino. Justamente essa função seria assumida mais tarde pelas quatro mulheres grisalhas da cena "Meia-noite", em especial pela Apreensão que inflige a cegueira ao centenário Fausto, titanicamente empenhado na expansão de seu império. O naufrágio do projeto colonizador que se desdobra no quinto ato se mostra assim, na leitura de Schlaffer, como que prefigurado "nas contradições do entrudo carnavalesco", precisamente pelas alegorias da negatividade que apontariam para o caráter vão dos empreendimentos econômicos surgidos com a derrocada das relações feudais.

Graças a procedimentos estéticos como tais antecipações cifradas, Goethe teria resgatado a alegoria da depreciação a que fora submetida por muitos de seus contemporâneos, a exemplo do que se observa também nesse severo veredito de Herder: "Um drama alegórico é o mais gélido jogo de sombras, no qual em contradição ininterrupta nulidades falam, nulidades agem". ${ }^{28}$ Naquilo em que Herder e tantos outros acusavam grave deficiência, o autor dos "gracejos muito sérios" do Fausto II (citando novamente palavras do próprio Goethe) reconheceu uma faceta genuína da contradição social, de tal modo que as nulidades que promovem ao longo da cena carnavalesca um "gélido jogo de sombras" também trazem em si, postula Schlaffer, a negação à qual todo elemento concreto sucumbe sob o domínio das abstrações. A forma alegórica, portanto, sempre se manifesta nesse drama enquanto conteúdo social.

Mas se for mesmo assim como pretende o sofisticado estudo de Heinz Schlaffer, se Goethe procurou de fato anunciar cifradamente a posterior entra- 
da em cena das mulheres grisalhas por intermédio das Parcas, Fúrias, Avareza, Medo e outras máscaras "negativas" do entrudo na corte imperial, não estaria também ele se revelando adepto do "divertissement" do alegorista, para lembrar a crítica de Lukács ao procedimento alegórico? Entre as cenas "Sala vasta" e "Meia-noite" medeiam afinal seis mil versos, no decorrer dos quais o enredo dramático experimenta a inflexão que leva à tragédia do colonizador, em cujo contexto a Apreensão se reveste de uma grandiosidade que dificilmente poderia ser forçada ao nível das aparições alegóricas do carnaval encenado no primeiro ato. ${ }^{29}$

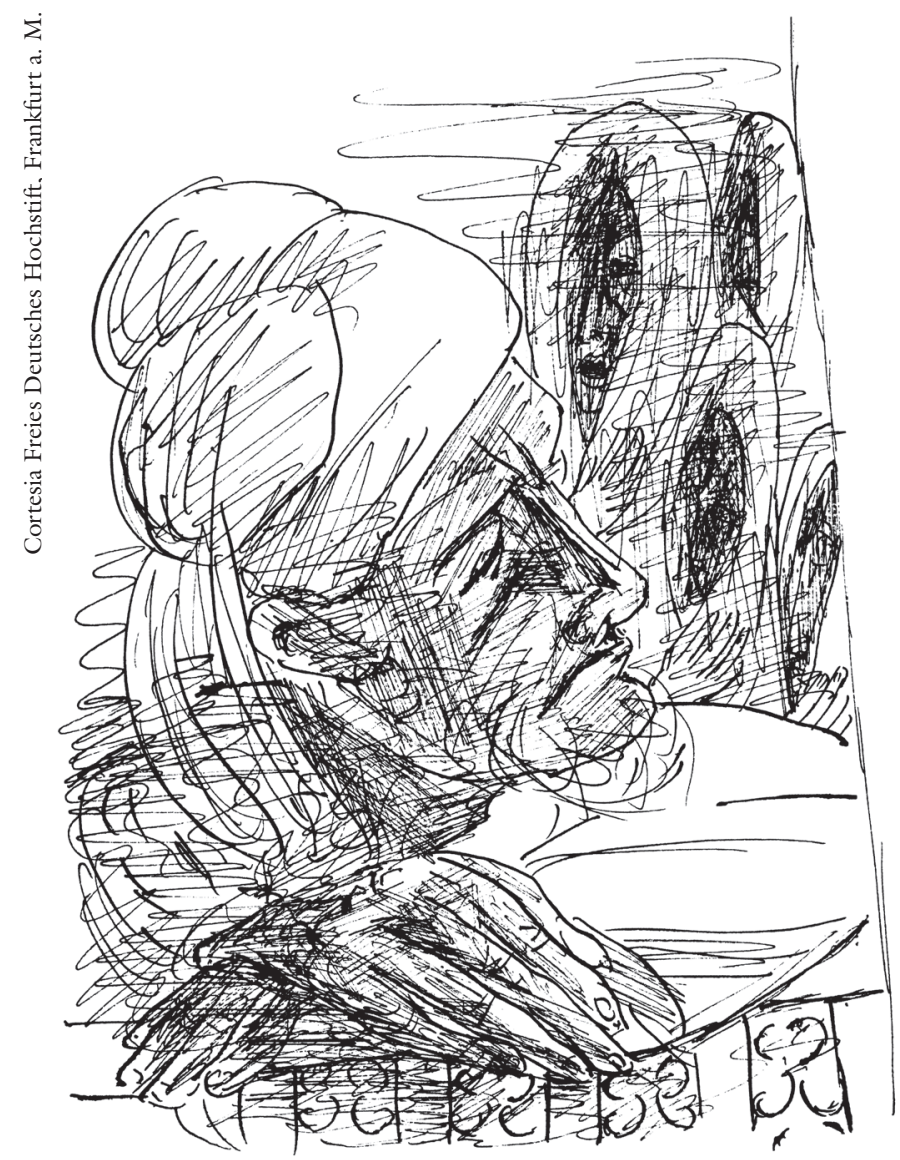

Desenho de Max Beckmann para o Fausto II: dos escombros do incêndio surgem as alegorias da Privação, Apreensão, Penúria e Insolvência.

Em que pesem, contudo, as ressalvas que se possam fazer à perspectiva crítica de Heinz Schlaffer em seu estudo sobre a Segunda Parte da tragédia goethiana enquanto "alegoria do século XIX", trata-se inquestionavelmente de uma contribuição extraordinária para a filologia fáustica à medida que, com sólidos fundamentos teóricos, aguça o olhar do leitor para a dimensão histórico-social da obra. Contudo, ao generalizar as ilações extraídas, à luz do marxismo, da autodenominação do Mancebo-Guia enquanto "alegoria" e do epíteto "herói 
mascarado" que o Arauto dirige ao desfilante fantasiado de deus da riqueza, Schlaffer é levado a atribuir ao Fausto II, também forçando nivelamentos bastante questionáveis, o significado dominante de iluminar avant la lettre os "conceitos fundamentais da economia política" desenvolvidos por Marx em seu opus magnum que, por sua vez, "poderia funcionar como direção cênica para algumas partes do Fausto II, em especial para o entrudo carnavalesco". E, na sequência, vem a constatação: "Se Marx ilustra a relação entre economia e sujeito com expressões e imagens alegóricas, e se as alegorias de Goethe tematizam por seu turno as condições econômicas dos papéis cênicos (Rollenspiele) - então o Capital e o Fausto II passam a comentar-se mutuamente" (op. cit., nota 25, p.54).

Decorre dessa abordagem que o leitor é cumulado com um número espantosamente alto de alegorias, ao passo que o poeta emprega o termo em apenas duas passagens, a primeira designando as figuras ao redor da carruagem alada (e não a totalidade dos participantes do entrudo, como quer Schlaffer) e a segunda referindo-se aos "valentões" recrutados por Mefistófeles para a guerra civil. Além dessas personagens, também poderiam ser consideradas como alegóricas, num sentido mais tradicional, as mulheres grisalhas que surgem ao velho colonizador na cena "Meia-noite" ou, na última cena do terceiro ato, Eufórion, alegoria da então moderna poesia (particularmente de Lord Byron) que nasce da união entre o cavaleiro medieval Fausto e Helena, e em pouco mais de duzentos versos - magistral condensação alegórica - cresce, atinge o seu apogeu e salta ao encontro da morte.

E quanto a tantas outras personagens que povoam os cinco atos do drama, como o Imperador e os dignitários do Estado, o Homúnculo e toda a legião de participantes da "Noite de Valpúrgis clássica”, Helena e Fórquias, Linceu, o Peregrino ou ainda Filemon e Baucis, depois os Lêmures, por fim os demônios da cena "Inumação" e, antes dos versos finais do Chorus mysticus, os anjos, patres e pecadoras penitentes tomados à "mitologia católica": será que nos encontramos também aqui perante alegorias? Para Schlaffer, fundamentalmente sim, uma vez que o processo de construção estética de tais figuras pressupõe a renúncia à expressão individual e, em muitos casos, a constituição da generalidade de "campos alegóricos", que são as "menores unidades de sentido" do Fausto II e surgem à medida que gêneros tradicionais, que em si podem prescindir inteiramente da estrutura ou disposição alegórica, são submetidos por Goethe aos princípios formais dessa sua obra de velhice. Por conseguinte, enquanto a Helena do terceiro ato se constituiria como "alegoria de si mesma", ou seja, do significado e imagem que possui na Antiguidade grega, as personagens de Baucis e Filemon, assim como a esfera vital que as cerca seriam alegóricas porque supostamente possuem o seu sentido fora de si, à medida que remetem ao antigo gênero do "idílio", conforme configurado no $8^{\circ}$ livro das Metamorfoses de Ovídio, que narra a história do casal de anciãos homônimo. ${ }^{30}$ Ter-se-ia aqui, portanto, uma dimensão que Goethe contrapõe à moderna técnica colonizadora vigente nas 
terras conquistadas ao mar, de tal modo que essas personagens, desprovidas da imanência do símbolo, tão somente significariam abstratamente uma forma de vida e de economia pré-capitalista, que no âmbito do antigo idílio havia sido a "moldura irrefletida do sonho poético de uma singela felicidade".

O episódio de Filemon e Baucis - narrado em versos cuja expressividade encontra poucos paralelos na literatura mundial, mas que na exegese de Schlaffer parece não assomar com relevância maior do que a passagem com as jardineiras apregoando sua mercadoria - é reduzido assim a uma dimensão abstrata e intelectualista, que se constitui por meio de uma operação "parasitária", já que o seu significado teria sido extraído de algo exterior a si, isto é, do antigo gênero "idílio".

Nessa perspectiva pode-se inferir então que também o par de tílias que sucumbe ao atentado orquestrado por Mefistófeles seria igualmente alegórico, pois faz parte do campo idílico em torno dos anciãos de Ovídio e remeteriam ao par de árvores (carvalho e tília) em que Filemon e Baucis se metamorfoseiam no momento da morte comum. E assim também Linceu, que apontaria para o integrante homônimo da mítica expedição dos argonautas, ou o Peregrino que, significando porventura o próprio Zeus acolhido por aqueles anciãos sob o disfarce de um simples andarilho, desempenha papel essencial no pequeno quadro que abre o último ato da tragédia.

Ao longo do Fausto II deparamos sem dúvida com personagens e eventos alegóricos no sentido tradicional do termo. Mas também muito do que parece renunciar à expressão individualizada e, por conseguinte, tender ao abstrato e genérico pode ser visto numa chave interpretativa não necessariamente comprometida com a antítese entre símbolo e alegoria esboçada pelas sentenças clássicas de Goethe. Desse novo ângulo crítico se delinearia a possibilidade de questionar a tese de que a alegoria tenha sido, por excelência, o procedimento artístico que o velho poeta, já em pleno século de Baudelaire e Marx, redescobriu para fazer frente a uma realidade que a seus olhos ia se tornando cada vez mais abstrata, artificial e virtual. Do mesmo modo se relativizaria a afirmação de que o Fausto II, ao fazer que conceitos fundamentais da economia política adentrassem o palco no entrudo carnavalesco do primeiro ato, tenha antecipado na dimensão estética a crítica da sociedade capitalista desenvolvida no Capital. Se o significado maior do texto goethiano residisse na capacidade de estabelecer e sustentar antecipadamente uma relação de comentário mútuo com a obra de Marx, isso não seria pouco. Mas o alcance dessa proeminente obra da literatura alemã e mundial vai certamente além da dimensão que lhe atribuiu a acurada abordagem de Heinz Schlaffer e seu potencial crítico talvez possa ser atualizado hoje por meio de uma leitura que, ultrapassando o campo teórico da alegoria (concebido em oposição diametral ao simbólico), busque aproximar-se do que Goethe chamou, em sua velhice, de fórmulas "ético-estéticas", em especial as que se terão constituído em torno da aspiração fáustica de subjugar a natureza, suprimir antigas tradições 
culturais e levantar um novo modelo de civilização em espaços ocupados anteriormente pelo mar. Essa nova leitura poderá mostrar então que a "atualidade quase que inimaginável" que Hans Christoph Binswanger atribuiu ao Fausto em seu estudo Dinheiro e magia não se restringe apenas à esfera da economia moderna.

\section{Notas}

1 Ästhetische Theorie. Frankfurt a. M, Suhrkamp, 1970 (citação à página 185).

2 Gespräche mit Goethe. Stuttgart, Philipp Reclam Verlag, 1994. Eckermann inseriu essas palavras de Goethe na terceira parte de seu livro (p.646-9). Por ocasião de uma conversa sobre a tradução francesa do Fausto por Gérard de Nerval, datada de três de janeiro de 1830 e que Eckermann dispôs na segunda parte do livro (p.396-7), o poeta teria dito: "O Fausto é algo inteiramente incomensurável e todas as tentativas de aproximá-lo do entendimento são vãs".

3 Carta de 8 de setembro de 1831 a Johann Sulpiz Boisserée, anunciando a conclusão da segunda parte do Fausto, após um esforço de várias décadas: "Aqui está ele então, tal como foi possível realizá-lo. E se ele ainda contém suficientes problemas, se de modo algum proporciona toda elucidação necessária, mesmo assim irá alegrar o leitor que sabe entender-se com gestos, acenos e leves alusões. Esse leitor encontrará até mesmo mais coisas do que eu pude oferecer". In: Goethes Briefe und Briefe an Goethe (org. Karl Robert Mandelkow), Munique, Deutscher Taschenbuch Verlag, 1988 (v.4, p.445-6).

4 Definição um tanto inusitada de "clássico" é apresentada pelo historiador Reinhart Kosellek em seu ensaio "A história extemporânea de Goethe". Comentando as diferentes posições de Friedrich Meineke, que postulava um retorno a Goethe após a catástrofe nacional-socialista, e de Karl Löwith, para quem não seria mais possível retornar ao autor do Fansto e tão pouco ultrapassá-lo, Kosellek arrisca as seguintes palavras: "A propósito, a definição momentânea de um clássico: impossível retornar a ele e igualmente impossível ir além dele". In: Vom Sinn und Unsinn der Geschichte. Aufsätze und Vorträge aus vier Jahrzehnten, Berlim, 2010.

5 Hans Christoph Biswanger: Geld und Magie. Eine ökonomische Deutung von Goethes Faust. Hamburgo: Murmann Verlag, 2009 (edição inteiramente revisada). Traduzido no Brasil por Maria Luiza de Borges (versos de Goethe por M. V. Mazzari), a partir porém da edição americana, que se baseia na $1^{\text {a }}$ edição alemã de 1985 , com o título Dinheiro e magia. Uma critica da economia moderna à luz do Fausto de Goethe (Rio de Janeiro, Zahar, 2011). Acompanham essa edição um longo prefácio ("Uma introdução à economia do Fausto de Goethe") e posfácio ("Fausto e a tragédia do desenvolvimento brasileiro") de Gustavo H. B. Franco.

6 Os versos do Fausto serão citados, como já acontece aqui, segundo a tradução de Jenny Klabin Segall, na edição bilíngue e ilustrada (Eugène Delacroix e Max Beckmann) com apresentação, comentários e notas de M. V. Mazzari: Primeira parte, São Paulo: Editora 34, 2013 (5.ed., revista e ampliada); Segunda parte, São Paulo: Editora 34, 2015 (4.ed., revista e ampliada). Embora admiravelmente fiel ao sentido do original (assim como à sua estrutura formal), essa tradução se permite por vezes liberdades condicionadas por necessidades métricas, rimáticas ou rítmicas. Em alguns desses 
casos se apresentará uma tradução literal que possa melhor subsidiar a argumentação crítica em andamento. (Nesse sentido, cumpre já assinalar que no original o Peregrino caracteriza as tílias como "escuras", e não "velhas", o que ecoa depois na bela expressão de Linceu "dupla noite das tílias".)

7 Costuma-se localizar o início simbólico da Revolução Industrial entre os anos 1765 e 1780, período em que James Watt inventa e aperfeiçoa a máquina a vapor (à qual Goethe faz sua Baucis aludir, de maneira muito cifrada, logo no início do $5^{\circ}$ ato). Valeria assinalar nesse contexto que a última leitura feita por Goethe, conforme o registro de 27 de fevereiro de 1832 em seu diário, constitui expressivo testemunho do interesse com que acompanhava os desdobramentos da revolução industrial: trata-se da descrição de uma viagem de trem de Liverpool a Manchester. Célebres no tocante à marcha avassaladora da industrialização são também as palavras que, no romance $O s$ anos de peregrinação de Wilhelm Meister (livro III, cap.13), o narrador coloca na boca de uma tecelã (ligada, portanto, à esfera do antigo trabalho artesanal): “O sistema maquinário, que vem se impondo mais e mais, me atormenta e angustia; como uma tempestade ele se aproxima pesadamente, aos poucos, aos poucos; mas já pegou o seu rumo, irá chegar e atingir em cheio". (Cerca de vinte anos mais tarde Marx e Engels constatavam, no segmento "Burgueses e operários" do Manifesto comunista, o colapso definitivo da manufatura, do sistema artesanal: "Mas os mercados continuavam a crescer, continuava a aumentar a necessidade de produtos. Também a manufatura já não bastava mais. Então o vapor e a maquinaria revolucionaram a produção industrial. A grande indústria moderna tomou o lugar da manufatura".)

8 O paradigma de um projeto "fáustico" é aquele que o próprio Goethe apresenta no último ato da tragédia, ou seja, o empenho do protagonista em conquistar terras ao mar por meio de gigantescas obras hidráulicas, baseadas sobretudo em densa rede de pôlderes e diques. Foram, em primeiro lugar, os Países Baixos que ofereceram ao poeta o modelo histórico para essa aspiração fáustica, seguidos de regiões no norte da Alemanha, como a Frísia. Outras referências factuais podem ser extraídas do imenso interesse com que o velho Goethe acompanhou os primeiros planos para a construção dos canais do Panamá e de Suez assim como os escritos e projetos de Saint-Simon e seus discípulos, para os quais obras de engenharia hidráulica, em especial de aterramento marítimo, representavam o mais alto conceito de dominação da natureza. Ver, sobre essa questão, o capítulo "O modelo fáustico e a protossociologia produtivista de Saint-Simon" no ensaio de Alfredo Bosi "Lendo o segundo Fausto de Goethe" in Fausto e a América Latina (org. Helmut Galle e M. V. Mazzari. São Paulo: Humanitas, 2010, p.51-71).

9 No dia 27 de setembro desse ano escrevia Goethe a Carl J. L. Iken: "Como muita coisa em nossa experiência não pode ser pronunciada de forma acabada e nem comunicada diretamente, há muito tempo elegi o procedimento de revelar o sentido mais profundo ao leitor atento por meio de configurações que se contrapõem umas às outras e ao mesmo tempo se espelham umas nas outras".

10 Conforme o relato autobiográfico de Poesia e verdade (livro III, cap.2), Wanderer (peregrino, viandante, caminhante) era o apelido do próprio Goethe em seus tempos de estudante. A figura do peregrino e o motivo do caminhar ou peregrinar atravessam toda sua obra, desde poemas de juventude (entre os quais a célebre "Canção noturna do peregrino") até o romance Os anos de peregrinação de Wilhelm Meister e a aparição do Peregrino no quinto ato do Fausto. E é justamente essa personagem, massacrada 
ao lado de Filemon e Baucis, que ocupa posição central no extraordinário livro de Michael Jaeger Wanderers Verstummen, Goethes Schweigen, Fausts Tragödie [O emudecer do Peregrino, o silêncio de Goethe, a tragédia de Fausto], publicado no final de 2014 (Würzburg, Königshausen \& Neumann).

11 Ursprung des deutschen Trauerspiels (Gesammelte Schriften, Band I - 1. Frankfurt a. M.: Suhrkamp, 1991, cap. "Allegorie und Trauerspiel”, p.336-65). Na edição brasileira: Origem do drama barroco alemão. Trad. Sergio Paulo Rouanet. São Paulo: Brasiliense, 1984, cap. "Alegoria e drama barroco", p.181-211).

12 Ästhetik. Teil I, cap.XVI: Der Befreiungskampf der Kunst. Munique: Luchterhand, 1963, segmento “Allegorie und Symbol”, p.727-75.

13 Numa conversa datada de 20 de dezembro de 1829, Goethe identificou o Mancebo-Guia (Knabe Lenker) à personagem de Eufórion, que faz sua aparição mais de quatro mil versos adiante. Ao espanto de Eckermann diante dessa incongruência, Goethe acrescenta ser isso possível por tratar-se de uma figura alegórica: "Nele encontra-se personificada a Poesia, a qual não está presa a nenhum tempo, a nenhum lugar e à nenhuma pessoa".

14 Sigo aqui a numeração estabelecida em 1907 por Max Hecker em sua edição de referência do volume Máximas e reflexões.

15 Bengt Algot Sørensen dedicou a essa questão o excelente ensaio: "Die 'zarte Differenz': Symbol und Allegorie in der ästhetischen Diskussion zwischen Schiller und Goethe" (in Walter Haug (org.) Formen und Funktionen der Allegorie. Stuttgart: Metzler Verlag, 1979, p.632-41).

16 Essa tendência schilleriana para o pensamento antitético também pode ser observada numa carta a Goethe datada de 23 de agosto de 1794, na qual as diferenças entre ambos são trabalhadas à luz da oposição "intuição-análise".

17 Bengt Algot Sørensen observa, no ensaio mencionado, que o tratado de Schiller teria estabelecido o primeiro fundamento para a estética romântica e que, além disso, toda sua obra teórica seria corresponsável pela sobrevalorização do pensamento abstrato e da filosofia, que Goethe considerava como traço característico de uma "época dos talentos forçados" (Epoche der forcierten Talente).

18 Ver, na mencionada edição brasileira da Primeira Parte do Fausto (nota 6), o apêndice "Uma autocensura de Goethe: a missa satânica da 'Noite de Valpúrgis"” (p.527-43).

19 Enquanto Hegel escrevia, em 1802 (Die Verfassung Deutschlands), que a Revolução Francesa depurara o conceito de liberdade de seu "vazio e indeterminação" (Leerheit und Unbestimmtheit), a visão goethiana da liberdade praticada durante a Revolução mostra-se igualmente submetida ao "espírito da história" absurdo e irracional que parece encarnar-se alegoricamente na Bruxa. Nesse sentido, vejam-se também esses versos acrescentados à cena "Taverna de Auerbach" após os acontecimentos de 1789: “Todos (cantam): Canibalmente bem estamos / Que nem quinhentos suínos! / Mefistófeles: Vê como o povo está livre (grifo meu) e à vontade!".

20 No ensaio acima citado (nota 4) escreve Kosellek: "Se Hegel pôde compreender toda a história do mundo enquanto fenomenologia do espírito sempre a caminho para chegar a si mesmo, então Goethe realizou esse trabalho para si próprio, excluindo a história do mundo. [...] Se Schiller, e com ele Hegel, enxergava na história do mundo (Weltgeschichte) o tribunal do mundo (Weltgericht), Goethe o entendia de maneira 
diferente: 'Para que todos possam assassinar uns aos outros / O Juízo Final foi postergado"'.

21 Nesse pseudônimo macarrônico construído por Vischer, Dentobold se constitui de uma referência ao verbo deuten (interpretar, fazer a exegese) ou ao substantivo Deutung (exegese, interpretação) e da desinência bold, remetendo a uma pessoa que pratica com frequência a ação indiciada na primeira parte da palavra ( Raufbold, nome que Goethe dá a um dos ajudantes de Mefisto, é um praticante contumaz de violências, agressões, arruaças - alguém que gosta de brigar, raufen). Em suas explanações teóricas sobre a "alegoria" Vischer, retomando e aprofundando a visão hegeliana, insiste em seu caráter gélido e escalvado: "ligação gélida de elementos do belo" é uma das definições apresentadas.

22 Castilho fecha com essas palavras a "Advertência do tradutor" que costuma preceder sua insólita tradução do Fausto I. Sobre as relações de Machado com a tragédia goethiana, ver o ensaio de Hélio de Seixas Guimarães "Machado de Assis, leitor do Fausto" in Fausto e a América Latina (org. Helmut Galle e M. V. Mazzari. São Paulo: Humanitas, 2010, p.339-51).

23 Uma extraordinária análise dessa última carta de Goethe nos oferece Albrecht Schöne no nono capítulo (“'Geheimnisse des Lebens' - An Wilhelm von Humboldt, 17. März 1832”) de seu livro Der Briefschreiber Goethe (Munique: C. H. Beck, 2015, p.36594). Fruto de um trabalho de várias décadas com a epistolografia de Goethe (estima-se que o poeta tenha escrito cerca de 25 mil cartas, das quais 15 mil estão depositadas no Arquivo Goethe e Schiller de Weimar), esse livro enfeixa nove estudos de cartas, redigidas num arco temporal de 68 anos, e três excursos dedicados ao sistema postal no ducado de Weimar, à prática goethiana de ditar cartas e, por fim, aos pronomes de tratamento mobilizados, que de modo algum se limitavam aos que se aproximam dos nossos "Você" e "Senhor" (Du e Sie).

24 No segmento "Die Allegorie" da Estética de Hegel (cap.3 da segunda parte: "Desenvolvimento do Ideal até as formas específicas do belo artístico"), leem-se, por exemplo, as seguintes palavras: "Um ser alegórico, por mais que se possa dar-lhe configuração humana, não alcança nem a individualidade concreta de um deus grego, nem a de um santo ou de qualquer outro sujeito real: porque ele [o ser alegórico], para tornar a subjetividade congruente com a abstração de seu significado, tem de esvaziá-la de tal maneira que leva ao desaparecimento de toda individualidade mais determinada. Por isso se diz com razão que a alegoria é gélida e escalvada [...], uma coisa ligada antes ao entendimento do que à contemplação concreta e à profundidade emocional da fantasia. Poetas como Virgílio têm a ver mais com seres alegóricos porque não sabem criar deuses individualizados, como os homéricos".

25 Das Kapital (v.3, cap.48: “Die trinitarische Formel” [A fórmula trinitária], p.838. Frankfurt a. M.: Verlag Marxistische Blätter GmbH, 1972 - edição idêntica ao volume 25 da Edição Marx-Engels (MEGA).

26 Faust Zweiter Teil - Die Allegorie des 19. Jahrhunderts. Stuttgart: Metzler Verlag, 1981. Essa síntese das "determinações essenciais da moderna sociedade burguesa" e das estruturas da forma alegórica encontra-se à página 98, fechando o capítulo "A gênese das relações alegóricas".

27 O bombardeio a que se refere Goethe aconteceu nos dias 13 e 14 de junho de 1796, ordenado pelo general francês Jean Baptiste Kléber com o intuito de obrigar à rendição as tropas austríacas que ocupavam então a cidade. 
28 Essa sentença de Herder encontra-se na terceira parte do volume Kalligone (capítulo "O belo contemplado como símbolo). Schriften zu Literatur und Philosophie 1792 1800 (v.8, Frankfurt a. M.: Deutscher Klassiker Verlag, 1998, citação à p.959).

29 Como o longo carnaval da corte imperial (922 versos), a única cena que o ultrapassa em extensão ("Noite de Valpúrgis clássica", com seus 1.483 versos) também constitui uma fonte privilegiada para interpretações que, se procedentes, revelariam Goethe como um alegorista do divertissement. Entre os acontecimentos que o poeta localiza às margens do rio Peneu, na penúltima etapa da cena, há a queda de um meteoro sobre a montanha levantada pouco antes por Seismo, esmagando Pigmeus, que pouco antes haviam massacrado as garças, e Grous, os quais vieram para vingar aquelas; a deformação da montanha pelo impacto do meteoro deflagra também uma disputa geológica entre os filósofos pré-socráticos Tales e Anaxágoras, que Goethe transforma anacronicamente em porta-vozes de duas correntes científicas de sua época, o netunismo e o vulcanismo. Não teríamos aqui questionáveis filigranas alegóricas se o sentido desse episódio fosse tão somente figurar desdobramentos da Revolução Francesa? Mas justamente isso já foi sustentado na fortuna crítica do Fausto, associando-se o meteoro ao "consulado" de 1799 presidido por Napoleão Bonaparte e os Grous, que buscam vingar os "parentes próximos", às tropas contrarrevolucionárias que, comandadas pelo duque de Braunschweig (Karl Wilhelm Ferdinand, 1735 - 1806), tentaram debalde invadir a França revolucionária (ver a esse respeito o comentário de Werner Keller em seu prefácio à excelente antologia Aufsätze zu Goethes 'Faust II'. Darmstadt: Wissenschaftliche Buchgesellschaft, 1992, p.XVIII). Guardadas as diferenças, seria o mesmo que explicar alegoricamente - como, aliás, já se fez - o grandioso poema "Le cygne", de Baudelaire, relacionando o cisne ao operariado sublevado em junho de 1848 e Andrômaca (viúva de Heitor, amante de Pirro e mulher de Heleno) à volúvel burguesia francesa que soube arranjar-se com Louis Philippe, depois com a Segunda República e, por fim, com o golpe de Estado de Napoleão III. Esse tipo de alegorese busca solver ou mensurar não apenas o enigma, mas também a própria “insolubilidade" ou "incomensurabilidade" da obra de arte, para voltar aos termos de Adorno e Goethe.

$30 \mathrm{Na}$ leitura marxista de Schlaffer, os atos de Helena e de Filemon e Baucis se entrelaçam também por meio do conceito de "imperialismo" tematizado no Fausto II: "No imperialismo cultural do terceiro ato anunciam-se o imperialismo político do quarto e o econômico do quinto. Do mesmo modo como Fausto conquistou Helena outrora, ele quer apropriar-se por fim do resto idílico de antigas formas de vida; mas com Filemon e Baucis o jogo é rápido: ele ordena o seu assassinato" (op. cit., p.121).

RESUMO - Este ensaio enfoca o Fausto de Goethe, mais particularmente sua Segunda Parte, à luz da longa tradição de reflexões teóricas sobre a alegoria e o símbolo. Essa tradição - que remonta, pelo menos, a Quintilianus (Institutio Oratoria, 95 a. C.) tem nas clássicas sentenças publicadas por Goethe no volume Máximas e reflexões um momento culminante, que servirá de parâmetro a teorizações posteriores, por mais diferentes que possam ser (como ilustram as posições de Walter Benjamin e Georg Lukács). Embora Goethe tenha condenado a alegoria durante o classicismo de Weimar, o Fausto II, "ocupação principal” (Hauptgeschäft) de seus últimos anos de vida, é considerado uma das obras mais alegóricas da literatura alemã. O ensaio busca discutir essa aparente 
contradição estruturando a argumentação crítica em três passos: o contexto em que Goethe desenvolveu suas concepções de símbolo e alegoria; os momentos da insólita recepção que coube ao Fausto II; a mudança de paradigma que se deu com a interpretação marxista que Heinz Schlaffer dedicou à Segunda Parte do drama enquanto "alegoria do século XIX". O ensaio acena ainda com a possibilidade de superar exegeses fundamentadas na relação antitética entre símbolo e alegoria recorrendo à ideia de "fórmula ético-estética", que Goethe esboçou em sua velhice ao mesmo tempo que abandonava aquela oposição concebida no período de convivência com Schiller. Desse novo ângulo de visão, o Fausto II poderá ser entendido, entre outras possibilidades de leitura, como expressiva "fórmula ético-estética" para epifenômenos da Revolução Industrial, como deixam entrever as cenas do Fausto escritas por volta de 1830.

PALAVRAS-CHAVE: Conceito de "clássico", Atualidade do Fausto, Teoria da alegoria e do símbolo, Classicismo de Weimar, Marxismo e interpretação alegórica, Heinz Schlaffer.

ABSTRACT - This essay focuses on Goethe's Faust, more specifically on Part II, in view of a long tradition of theoretical reflections on allegory and symbol. In this tradition, which dates back at least to Quintilianus (Institutio oratoria, 95 BC), Goethe's classic assertions published in Maxims and reflections are a culminating moment, and will become a parameter for later theories, as varied as they might be (as illustrated by the positions of Walter Benjamin and Georg Lukács). Although Goethe condemned the use of allegory during the Weimar Classicism, Faust II, "the main occupation" (Hauptgeschäft) of his later years, is considered one of the most allegorical works of German literature. This paper seeks to discuss this apparent contradiction by structuring a critical argument in three steps: the context in which Goethe developed his concepts of symbol and allegory; the uncommon responses regarding the reception of Faust II; and the paradigm shift that occurred with Heinz Schlaffer's Marxist interpretation of the Second Part as an "allegory of the nineteenth century". The essay indicates the possibility of overcoming exegeses grounded on an antithetical relation between symbol and allegory by resorting to the idea of an "ethical-aesthetic formula", which Goethe outlined in his old age when he abandoned his own opposition conceived during his period of closeness with Schiller. Among other possibilities, from this new point of view, Faust II can be understood as an expressive "ethical- aesthetic formula" for epiphenomena of the Industrial Revolution, as evinced in the scenes of Faust II written around 1830.

KEYWORDS: Concept of "classic"; Contemporariness of Faust; Theory of allegory and symbol, Weimar Classicism, Marxism and allegorical interpretation, Heinz Schlaffer.

Marcus Vinicius Mazzari é professor de Teoria Literária na USP. É também tradutor e autor, entre outros trabalhos, de Labirintos da aprendizagem (Editora 34, 2010); elaborou os prefácios, comentários e notas aos volumes Fausto I (Editora 34, 2013 - 5.ed.) e Fausto II (Editora 34, 2015 - 4.ed.), em tradução de Jenny Klabin Segall. @- mazzari@usp.br

Recebido em 12.4.2015 e aceito em 22.6.2015.

${ }^{\text {I }}$ Faculdade de Filosofia, Letras e Ciências Humanas, Universidade de São Paulo, São Paulo/SP, Brasil. 